\title{
Effect of Pentoxifylline Administration on Hemoglobin Level of Hemodialysis Patients
}

\author{
SARAH A. MOHAMED, M.Sc.*; ATEF M. TAHA, M.D.*; SHEREEN A. ABDEL-SALAM, M.D.* and \\ MAALY M. MABROUK, M.D.** \\ The Departments of Internal Medicine* and Clinical Pathology**, Faculty of Medicine, Tanta University
}

\begin{abstract}
Background: Anemia is a common complication of endstage renal disease despite sufficient iron stores. That is mainly due to the effect of chronic inflammation.

Aim of Study: Our study investigated the effect of using a know drug used in intermittent claudication (named pentoxifylline) as an adjuvant to ESA to improve anemia of hemodialysis patients.

Patients and Method: Fifty hemodialysis anemic patients were included. They were assigned to two groups of equal numbers. Oral Pentoxifylline $400 \mathrm{mg}$ once daily was added to the treatment group which was compared to the control group over a six months period regarding hemoglobin, hematocrit, serum albumin and CRP.

Results: We found no significant difference in hemoglobin or hematocrit between the two groups at the end of the study. However serum albumin was significantly higher in the treatment group $(4.2 \pm 0.3)$ than the control group $(3.8 \pm 0.4)$ $p<0.001$ at the end of the study. In addition, CRP was significantly lower in the treatment group $(8.8 \pm 5.4)$ versus $(17.1 \pm$ 13.3 ) for the treatment and control group respectively; $p=0.005$ ).

Conclusion: Pentoxifylline had a significant effect in improving the chronic inflammatory state but its use in improving anemia of hemodialysis patients still needs further research.
\end{abstract}

Key Words: Pentoxifylline - Anemia - Hemoglobin - Hemodialysis.

\section{Introduction}

CHRONIC kidney disease (CKD) is defined as kidney damage or decreased kidney function for three or more months irrespective of the cause. Kidney damage can be demonstrated through urine analysis, kidney imaging or renal biopsy [1]

In countries of North Africa, the reported annual incidence of ESRD was 34-200 per million popu-

Correspondence to: Dr. Sarah A. Mohamed, E-Mail: Sara.abdelmegeed@med.tanta.edu.eg. lation with a prevalence of 30-430 patients pmp. The incidence in Egypt was $74 \mathrm{pmp}$ with a prevalence of 264 per million patients [2].

Risk factors for CKD and its progression to end-stage renal disease (ESRD) include diabetes mellitus, hypertension, smoking, hyperuricemia, recurrent renal stones, and several glomerular diseases either primary or secondary [3]

End-stage renal disease patients are vulnerable to a lot of complications such as chronic kidney disease-mineral bone disease, dyslipidemia, malnutrition and anemia being the most common complication contributing to a large percentage of morbidity and mortality especially from cardiovascular events [4].

Anemia is defined as hemoglobin $(\mathrm{Hb})<13 \mathrm{~g} / \mathrm{dl}$ in adult male and $<12 \mathrm{~g} / \mathrm{dl}$ in adult female [5]. Many factors contribute to the development of anemia in CKD and ESRD patients. Erythropoietin deficiency is the principal cause of anemia in those patients. However, iron deficiency, vitamin B 12 and folic acid deficiencies, hyperparathyroidism, and chronic inflammation are all contributing factors to the development of anemia in ESRD patients [6]

Erythropoietin-stimulating agent (ESA) is the main modality for treating anemia in ESRD patients with a dose of $60-150 \mathrm{IU} / \mathrm{kg} / \mathrm{wk}$ which needs sufficient iron stores to be accomplished first [7] .

Chronic inflammation frequently hinders the patient response to ESA necessitating to increase its dose. Administration of pentoxifylline as an anti-inflammatory drug in ESRD patients on ESA therapy has been studied in a few numbers of clinical trials $[\mathbf{8 , 9}$. 


\section{Patients and Methods}

Our study was conducted on ESRD patients in the two hemodialysis centers of Tanta University Hospital during the period from November 2017 to the end of April 2018 (six months period).

Type of the study: Open-label randomized controlled clinical trial.

Inclusion criteria: (Patients with ESRD on HD who have hemoglobin $<11 \mathrm{~g} / \mathrm{dl}$, taking Erythropoietin alfa 4000-12000I.U/wk and having a urea reduction ratio $>65 \%$ ). There were 57 patients who met the inclusion criteria out of 158 patients.

Exclusion criteria: Iron deficiency anemia with transferrin saturation $<30 \%$, intact PTH $>300 \mathrm{pg} / \mathrm{ml}$, vitamin B12 or folate deficiency (evidenced by macrocytosis), history of intolerance to pentoxifylline or other xanthine derivatives, recent retinal or cerebral hemorrhage or active peptic ulcer disease, pregnancy or breastfeeding, presence of systemic hematological disease or known hemoglobinopathy, major surgery, infection, acute myocardial infarction, or malignancy within the last three months and patients who refused to participate in the study.

Study approval: Permission obtained from the Research Ethics Committee as a part of the Quality Assurance Unit in the Faculty of Medicine Tanta University. An informed written consent was obtained from all participants in this research.

Study population: 57 out of 158 patients met the inclusion criteria. They were randomly divided between treatment and control groups.

Group I: 29 patients ( 25 completed the study) that received the study agent $(400 \mathrm{mg}$ of oral pentoxifylline daily for 6 months), besides the appropriate weight-based dose of ESA (60-150I.U/ $\mathrm{kg} / \mathrm{wk})$.

Group II: 28 patients ( 25 completed the study) who did not receive pentoxifylline but they received the appropriate dose of ESA. They were used as a control group and compared to group 1 concerning the primary and the secondary outcomes.

Four patients were excluded from the treatment group (one patient refused to complete the study and three patients were nonadherent to the drug). Three patients were excluded from the control group (two patients transferred to other hemodialysis centers and one patient died).

All patients included in this study were subjected to : Through history taking, complete physical examination, blood samples obtained for calculating the urea reduction ratio (target $>65 \%$ ) and baseline laboratory investigations in the form of (Full blood count, transferrin saturation, intact Parathyroid hormone level, serum albumin and C-reactive protein.

Pentoxifylline at a dose of $400 \mathrm{mg} /$ day orally was started for the intervention group. Follow-up of CBC, serum albumin and CRP every two months was done for investigating any difference between the two groups. We followed the patients up weekly for any potential side effects or drug intolerance.

\section{Statistical analysis:}

The quantitative variables were presented as a mean \pm standard deviation (SD) and compared by $t$-test and ANOVA in case that variables are normally distributed and by Mann-Whitney U test in case that they are not normally distributed. The categorical variables were statistically analyzed by the chi-square test. SPSS 25.0 software was used for analysis and $p$-values equal to or less than 0.05 were considered significant.

\section{Results}

We had a total of 158 ESRD patients on HD in our units. We have found that $36 \%$ of them have anemia with $\mathrm{Hb}<11 \mathrm{~g} / \mathrm{dl}$ despite having sufficient iron stores (transferrin saturation $\geq 30 \%$ ) and appropriate dose of erythropoietin alfa/week.

Out of 57 patients meeting the inclusion criteria (29 in the treatment group, 28 in the control group), Fifty patients completed the study ( 25 patients in each group). There was no significant difference in the baseline characteristics between the two groups (except for age which was significantly higher in the treatment group) as demonstrated in Table (1). $p$-value $\leq 0.05$ is considered statistically significant.

By comparing baseline hemoglobin and hematocrit to the same parameters throughout the study period in each group separately, there is a significant increase in hemoglobin and hematocrit from baseline within each group, $p$-value $<0.001 *$ (Tables 2,3 ). While albumin and CRP had no significant changes from baseline in the control group ( $p$ value 0.173 and 0.535 for albumin and CRP respectively), there was a significant increase in serum albumin and a corresponding decrease in CRP from baseline in the treatment group ( $p$-value $<0.001 *$ ) (Tables 4,5).

By comparing the two groups regarding $\mathrm{Hb}$ and HCT at 2, 4 and 6 months from the beginning, there was no significant difference in $\mathrm{Hb}$ or HCT 
throughout and at the end of the study between the two groups. $p$-value 0.094 and 0.086 for $\mathrm{Hb}$ and HCT respectively by the end of six months (Tables $6,7)$. Albumin has significantly increased ( $p$ value $<0.001^{*}$ ) while CRP has significantly de- creased ( $p$-value $\left.0.005^{*}\right)$ in the treatment group than the control group at the end of the study (Tables 8,9). Finally, there were no reported side effects related to drug administration throughout the study period.

Table (1): Comparing baseline characteristics in both groups.

\begin{tabular}{|c|c|c|c|c|c|c|}
\hline Variable & \multicolumn{2}{|c|}{$\begin{array}{l}\text { Treatment } \\
\text { group }(n=25)\end{array}$} & \multicolumn{2}{|c|}{$\begin{array}{l}\text { Control } \\
\text { group }(n=25)\end{array}$} & $\begin{array}{l}\text { Test of } \\
\text { significance }\end{array}$ & $\begin{array}{c}p- \\
\text { value }\end{array}$ \\
\hline $\begin{array}{l}\text { Age (years): } \\
\quad \text { Mean } \pm \mathrm{SD}\end{array}$ & \multicolumn{2}{|c|}{$50.9 \pm 10.6$} & \multicolumn{2}{|c|}{$42.7 \pm 13.6$} & $t=2.381 *$ & $0.022 *$ \\
\hline $\begin{array}{l}\text { Sex: } \\
\text { Male } \\
\text { Female }\end{array}$ & \multicolumn{2}{|l|}{$\begin{array}{l}13 \\
12\end{array}$} & $\begin{array}{l}11 \\
14\end{array}$ & & $\chi^{2}=0.321$ & 0.571 \\
\hline $\begin{array}{l}\text { Duration of ESRD (years) } \\
\text { Mean } \pm \text { SD } \\
\text { Median }\end{array}$ & \multicolumn{2}{|c|}{$\begin{array}{l}3.8 \pm 1.4 \\
4\end{array}$} & $\begin{array}{l}3.8 \pm 1.6 \\
4\end{array}$ & & $\mathrm{U}=308.00$ & 0.929 \\
\hline $\begin{array}{l}H b(g / d l): \\
\quad \text { Mean } \pm \mathrm{SD}\end{array}$ & \multicolumn{2}{|c|}{$8.8 \pm 1.2$} & $8.9 \pm 1.0$ & & $t=0.489$ & 0.627 \\
\hline $\begin{array}{l}H C T(\%): \\
\quad \text { Mean } \pm \mathrm{SD}\end{array}$ & \multicolumn{2}{|c|}{$26.8 \pm 3.4$} & $27.0 \pm 2.9$ & & $t=0.192$ & 0.848 \\
\hline $\begin{array}{l}T S A T(\%): \\
\text { Mean } \pm \text { SD } \\
\text { Median }\end{array}$ & \multicolumn{2}{|c|}{$\begin{array}{l}45.3 \pm 16.6 \\
39\end{array}$} & $\begin{array}{l}55.1 \pm 20 . \\
50\end{array}$ & & $\mathrm{U}=221.50$ & 0.077 \\
\hline $\begin{array}{l}\text { iPTH }(\mathrm{pg} / \mathrm{ml}): \\
\quad \text { Mean } \pm \mathrm{SD}\end{array}$ & \multicolumn{2}{|c|}{$166.0 \pm 81.2$} & $190.3 \pm 69$ & & $t=1.139$ & 0.260 \\
\hline $\begin{array}{l}\text { Albumin }(g / d l): \\
\quad \text { Mean } \pm \text { SD }\end{array}$ & \multicolumn{2}{|c|}{$3.6 \pm 0.4$} & $3.8 \pm 0.4$ & & & 0.173 \\
\hline $\begin{array}{l}C R P(m g / d l): \\
\text { Mean } \pm \text { SD } \\
\text { Median }\end{array}$ & \multicolumn{2}{|c|}{$\begin{array}{l}21.8 \pm 17.4 \\
16.0\end{array}$} & $\begin{array}{l}16.1 \pm 13 \\
12.0\end{array}$ & & $\mathrm{U}=255.50$ & 0.266 \\
\hline \multicolumn{7}{|c|}{ Table (2): Comparison between the different periods according to $\mathrm{Hb}$ in each group. } \\
\hline $\mathrm{Hb}$ & Baseline & $2 \mathrm{M}$ & $4 \mathrm{M}$ & $6 \mathrm{M}$ & $\mathrm{F}$ & $p$-value \\
\hline $\begin{array}{l}\text { Treatment group }(n=25) \text { : } \\
\text { Mean } \pm \text { SD. }\end{array}$ & $8.8 \pm 1.2$ & $9.5 \pm 1.1$ & $9.6 \pm 1.2$ & $10.5 \pm 1.4$ & $25.903^{*}$ & $<0.001 *$ \\
\hline Sig. bet. Periods & & $<0.001 *$ & $0.006^{*}$ & $<0.001 *$ & & \\
\hline $\begin{array}{l}\text { Control group }(n=25): \\
\text { Mean } 1 \text { SD. }\end{array}$ & $8.9 \pm 1.0$ & $9.4 \pm 1.0$ & $9.6 \pm 1.2$ & $9.9 \pm 1.0$ & $16.219^{*}$ & $0.001 *$ \\
\hline Sig. bet. Periods & & $0.003 *$ & $0.002 *$ & $<0.001 *$ & & \\
\hline \multirow{2}{*}{\multicolumn{7}{|c|}{$\begin{array}{ll}\text { F: } \mathrm{F} \text { test (ANOVA) with repeated measures. } & \text { *: Statistically significant at } p \leq 0.05 . \\
\text { Each } 2 \text { periods was done using Post Hoc Test (Bonferroni). } & \text { m: Month. } \\
& \\
\text { Table (3): Comparison between the different periods according to HCT in each group. }\end{array}$}} \\
\hline & & & & & & $p$-value \\
\hline $\begin{array}{l}\text { Treatment group }(n=25) \text { : } \\
\text { Mean } \pm \text { SD. }\end{array}$ & $26.8 \pm 3.4$ & $28.7 \pm 3.1$ & $28.9 \pm 3.7$ & $31.6 \pm 4.2$ & $21.742 *$ & $<0.001 *$ \\
\hline Sig. bet. Periods & & $<0.001 *$ & $0.036^{*}$ & $<0.001 *$ & & \\
\hline $\begin{array}{l}\text { Control group }(n=25) \text { : } \\
\text { Mean } \pm \text { SD. }\end{array}$ & $27.0 \pm 2.9$ & $28.4 \pm 2.9$ & $29.0 \pm 3.6$ & $29.7 \pm 2.9$ & $4.105^{*}$ & $0.001 *$ \\
\hline Sig. bet. Periods & & $0.003 *$ & $0.003 *$ & $<0.001 *$ & & \\
\hline
\end{tabular}

F: $F$ test (ANOVA) with repeated measures.

Each 2 periods was done using Post Hoc Test (Bonferroni)

$*$ : Statistically significant at $p \leq 0.05$. 
Table (4): Comparison between the different periods according to albumin in each group.

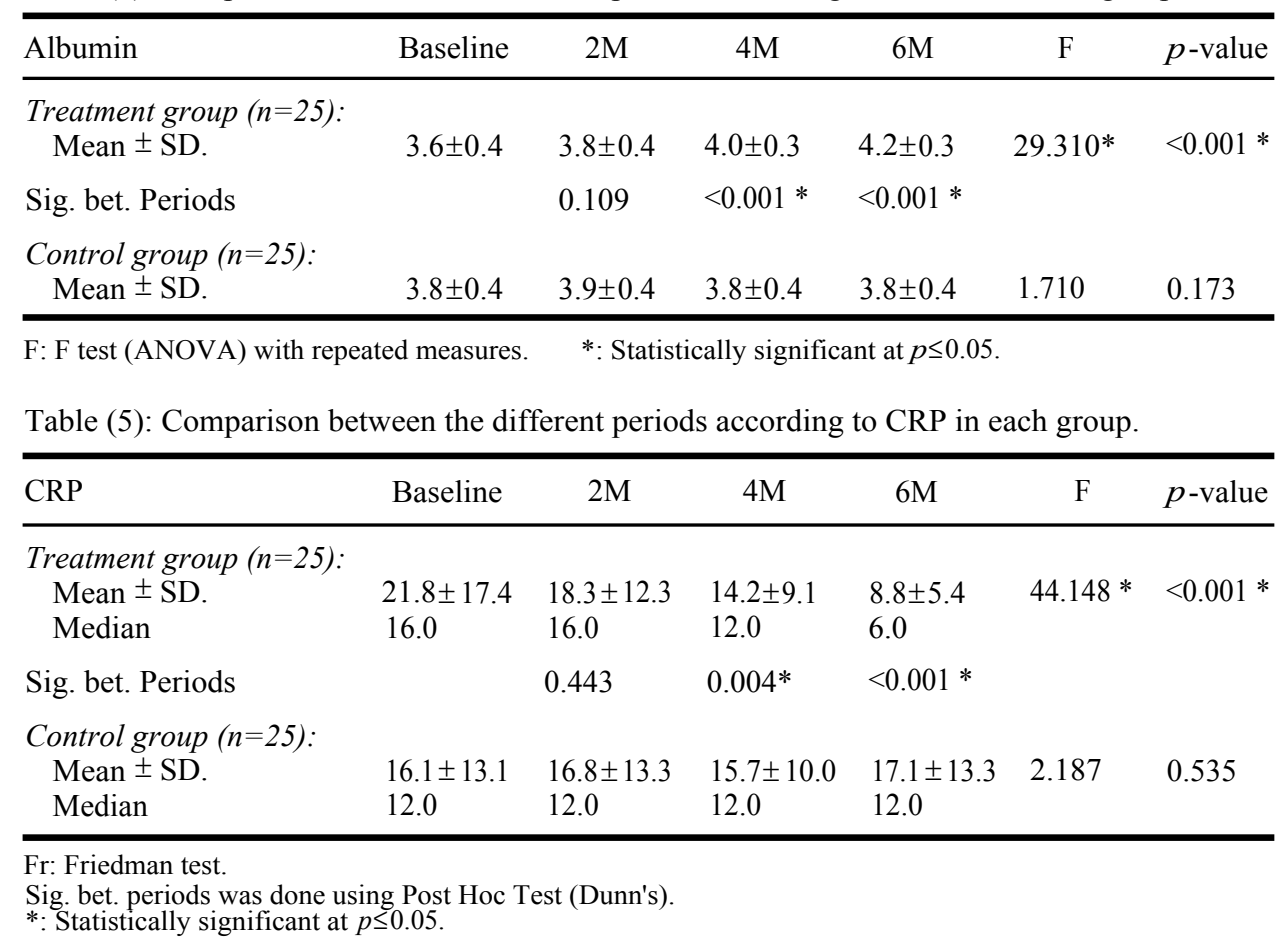

Table (6): Comparison between the two studied groups according to $\mathrm{Hb}$.

\begin{tabular}{lllll}
\hline $\mathrm{Hb}$ & $\begin{array}{c}\text { Treatment } \\
\text { group (25) }\end{array}$ & $\begin{array}{c}\text { Control } \\
\text { group (25) }\end{array}$ & $t$ & $p$-value \\
\hline $\begin{array}{c}\text { Baseline: } \\
\text { Mean } \pm \mathrm{SD}\end{array}$ & $8.8 \pm 1.2$ & $8.9 \pm 1.0$ & 0.489 & 0.627 \\
$\begin{array}{c}\text { months: } \\
\text { Mean } \pm \text { SD }\end{array}$ & $9.5 \pm 1.1$ & $9.4 \pm 1.0$ & 0.352 & 0.727 \\
$\begin{array}{c}\text { months: } \\
\text { Mean } \pm \text { SD }\end{array}$ & $9.6 \pm 1.2$ & $9.6 \pm 1.2$ & 0.058 & 0.954 \\
$\begin{array}{c}\text { 6 months: } \\
\text { Mean } \pm \text { SD }\end{array}$ & $10.5 \pm 1.4$ & $9.9 \pm 1.0$ & 1.707 & 0.094 \\
\hline
\end{tabular}

Table (8): Comparison between the two studied groups according to albumin.

\begin{tabular}{|c|c|c|c|c|c|c|c|c|c|}
\hline $\begin{array}{c}\text { Albumin } \\
\text { Mean } \pm \text { SD }\end{array}$ & $\begin{array}{l}\text { Treatment } \\
\text { group (25) }\end{array}$ & $\begin{array}{c}\text { Control } \\
\text { group (25) }\end{array}$ & $t$ & $p$-value & CRP & $\begin{array}{l}\text { Treatment } \\
\text { group (25) }\end{array}$ & $\begin{array}{c}\text { Control } \\
\text { group (25) }\end{array}$ & $\mathrm{U}$ & $p$-value \\
\hline $\begin{array}{l}\text { Baseline: } \\
\quad \text { Mean } \pm \mathrm{SD}\end{array}$ & $3.6 \pm 0.4$ & $3.8 \pm 0.4$ & 1.383 & 0.173 & $\begin{array}{l}\text { Baseline: } \\
\text { Mean } \pm \text { SD } \\
\text { Median }\end{array}$ & $\begin{array}{l}21.8 \pm 17.4 \\
16.0\end{array}$ & $\begin{array}{l}16.1 \pm 13.1 \\
12\end{array}$ & 255.50 & 0.266 \\
\hline $\begin{array}{l}2 \text { months: } \\
\quad \text { Mean } \pm \text { SD }\end{array}$ & $3.8 \pm 0.4$ & $3.9 \pm 0.4$ & 0.673 & 0.504 & $\begin{array}{l}2 \text { months: } \\
\quad \text { Mean } \pm \text { SD } \\
\text { Median }\end{array}$ & $\begin{array}{l}18.3 \pm 12.3 \\
16\end{array}$ & $\begin{array}{l}16.8 \pm 13.3 \\
12\end{array}$ & 269.50 & 0.399 \\
\hline $\begin{array}{l}4 \text { months: } \\
\text { Mean } \pm \text { SD }\end{array}$ & $4.0 \pm 0.3$ & $3.8 \pm 0.4$ & $2.972 *$ & $0.005^{*}$ & $\begin{array}{l}4 \text { months } \\
\quad \text { Mean } \pm \text { SD } \\
\text { Median }\end{array}$ & $\begin{array}{l}14.2 \pm 9.1 \\
12\end{array}$ & $\begin{array}{l}15.7 \pm 10.0 \\
12\end{array}$ & 276.00 & 0.476 \\
\hline $\begin{array}{l}6 \text { months: } \\
\quad \text { Mean } \pm \text { SD }\end{array}$ & $4.2 \pm 0.3$ & $3.8 \pm 0.4$ & $4.397 *$ & $<0.001^{*}$ & $\begin{array}{l}6 \text { months: } \\
\text { Mean } \pm \text { SD } \\
\text { Median }\end{array}$ & $\begin{array}{l}8.8 \pm 5.4 \\
6\end{array}$ & $\begin{array}{l}17.1 \pm 13.3 \\
12\end{array}$ & $168.50 *$ & $0.005^{*}$ \\
\hline
\end{tabular}

Table (7): Comparison between the two studied groups according to hematocrit.

\begin{tabular}{llccc}
\hline Hematocrit & $\begin{array}{c}\text { Treatment } \\
\text { group (25) }\end{array}$ & $\begin{array}{c}\text { Control } \\
\text { group (25) }\end{array}$ & $t$ & $p$-value \\
\hline $\begin{array}{c}\text { Baseline: } \\
\text { Mean } \pm \text { SD }\end{array}$ & $26.8 \pm 3.4$ & $27.0 \pm 2.9$ & 0.192 & 0.848 \\
$\begin{array}{c}2 \text { months: } \\
\text { Mean } \pm \text { SD }\end{array}$ & $28.7 \pm 3.1$ & $28.4 \pm 2.9$ & 0.347 & 0.730 \\
$\begin{array}{c}4 \text { months } \\
\text { Mean } \pm \text { SD }\end{array}$ & $28.9 \pm 3.7$ & $29.0 \pm 3.6$ & 0.112 & 0.911 \\
$\begin{array}{c}6 \text { months: } \\
\text { Mean } \pm \text { SD }\end{array}$ & $31.6 \pm 4.2$ & $29.7 \pm 2.9$ & 1.753 & 0.086 \\
\hline
\end{tabular}

$t$ : Student $t$-test is the test of significance.

Table (9): Comparison between the two studied groups according to CRP.

*: Statistically significant at $p \leq 0.0$ 


\section{Discussion}

Anemia is considered as the most common complication of CKD and ESRD patients reducing their quality of life and exacerbating their cardiovascular risk and mortality [10]. The treatment is based on giving erythropoietin stimulating agents after repletion of iron stores [11]. It is worthy to say that a considerable percent of hemodialysis patients still suffer from anemia despite having sufficient iron stores and the appropriate weightbased dose of ESA. The persistent anemia in such patients is mainly due to increased inflammatory process and oxidative stress that impair their response to erythropoietin preparations $[\mathbf{1 2 , 1 3 ]}$

Inflammation can be demonstrated through nonexpensive laboratory markers as CRP and serum albumin $[\mathbf{1 4 , 1 5}]$. They are considered as acute phase reactants and usually affected by the continuous inflammatory process [16]. In such condition, patients may get benefit from increasing the weekly dose of ESA to a maximum of 300 units $/ \mathrm{kg} /$ week subcutaneously. Other patients will not get benefit from that maximum dose and hence meet the definition of ESA resistance [17]. However, increasing the dose of ESA costs a lot and render them nonadherent to such high doses [18]. Moreover, ESA has a number of adverse effects like hypertension, muscle and joint pain, fever, dizziness, headache, depression and more seriously, vascular occlusion, stroke, myocardial infarction and increased risk of death in cancer patients [19].

Trying to overcome the process of chronic inflammation by using a cheap anti-inflammatory drug with no considerable side effects like pentoxifylline sounds to be a good idea to improve the response to erythropoietin preparations.

This study revealed that $36 \%$ of hemodialysis patients have anemia despite sufficient iron stores and having the appropriate weight-based dose of erythropoietin alfa per week $(\mathrm{Hb}<11 \mathrm{gm} / \mathrm{dl}$, ESA dose of 4000-12000IU/wk).

Our percent was higher than that reported by Cooper and colleagues in 2004 [20]. They found that $10.4 \%$ of anemic ESRD patients had sufficient iron stores and adequate dose of ESA. However, they selected patients with $\mathrm{Hb}<10.7$ despite receiving an ESA dose equal to or more than 12000IU /week. On the other hand, Shahbazian et al., [8] reported a higher percent than ours. They found that $53 \%$ of their HD patients had anemia despite sufficient iron stores and appropriate ESA dose after exclusion of known causes of ESA hyporesponsiveness. Although the age and duration of
ESRD of the participants (in our study and their study) were nearly equal, that percent variation may be the result of the underlying unreported comorbidities.

In our study, when we compared $\mathrm{Hb}$ and HCT between the two groups, there was no significant difference between both groups at the end of the study. Our finding is consistent with GonzalezEspinoza and colleagues [21]. Who conducted a study on $36 \mathrm{HD}$ patients divided equally between treatment (using pentoxifylline $400 \mathrm{mg}$ daily) and placebo groups. The study was controlled, randomized, double-blind that lasted for 4 months. The primary outcome was the change in serum inflammatory markers (TNF-alfa, IL-6, and CRP) by the end of the study. They found no significant difference in $\mathrm{Hb}$ between both groups by the end of the study period. That is similar to our finding as regard to hemoglobin and hematocrit, but we have the advantage of a larger number of included patients and longer period.

In another study conducted by Mortazavi and colleagues [22]. In Iran, $50 \mathrm{HD}$ patients were divided equally between treatment and placebo groups. By the end of the 6 months study period, there were no significant changes in hemoglobin in both groups.

In a systematic review [23] conducted in 2015, they included 11 studies (377 patients) including seven randomized controlled trials (all comparing pentoxifylline to placebo or standard therapy) one retrospective case-control study and three prospective uncontrolled studies. Overall, pentoxifylline increased hemoglobin in three uncontrolled studies but such improvement was not confirmed in a meta-analysis of seven studies.

On the other hand, Navarro and colleagues. [24] studied 7 ESRD patients in Spain. They were treated with $400 \mathrm{mg}$ oral pentoxifylline daily for 6 months and compared them with 5 patients as a control group. At the end of the study, they showed a significant increase in $\mathrm{Hb}$ and $\mathrm{HCT}$ amounts in the treatment group. However, the small number of included patients was one of the limitations of that trial. They also showed a significant decrease in TNF- $\alpha$ in the treatment group $(p=0.01)$, proving the anti-inflammatory effect of the drug which was proved in our study using different nonexpensive inflammatory markers (serum albumin and CRP).

Moreover, Cooper and colleagues [20]. Studied 12 ESRD patients in the United Kingdom with the administration of $400 \mathrm{mg}$ oral pentoxifylline daily for 4 months. They showed significant increase in 
$\mathrm{Hb}$ and significant decrease in TNF- ct and IFN-y. The study was uncontrolled which is considered as one of its limitations. Other limitations are the short duration of the study and the small number of included patients.

In addition, a retrospective case-control study conducted by Mora-Gutiérrez and colleagues (2013) [25] in Spain, studied 18 HD patients receiving pentoxifylline $400 \mathrm{mg}$ twice daily for 6-32 months and other 18 controls. They showed a significant increase in $\mathrm{Hb}$ with a significant reduction in the dose of ESA in the pentoxifylline group. However, their patients used a higher dose of pentoxifylline (double the dose) than that used in our trial. In 2017, Shahbazian H and colleagues [8] studied the administration of pentoxifylline in 19 ESRD patients with erythropoietin-resistant anemia versus a control group of the same characteristics for 6 months. By the end of the study, hemoglobin and hematocrit were significantly higher in the treatment than the control group.

In our study, markers of inflammation (CRP and serum albumin) showed significant improvement in the treatment group by the end of the study while showed no change in the control group.

That was in agreement with Gonzalez-Espinoza and colleagues [21] that showed a significant reduction in all inflammatory markers named CRP, IL-6, and TNF-alfa in the treatment group by the end of the study. In our study, serum albumin increased significantly in the treatment group in agreement with the study conducted by Shahbazani et al., [8] in 2017. On the other hand, the study conducted by Antunes and colleagues (2014) [26] showed no significant changes in serum albumin or CRP between both groups at the end of the study.

Our limitations include a short period of the study and a small number of included patients (despite including larger number than other studies). The significant difference in the age between the two groups can also be considered as one of the limitations of this study.

We recommend that further multicentric clinical trials matched for age and comorbidities should be conducted for longer periods before deciding to use the drug as an adjuvant to ESA in hemodialysis patients.

\section{Acknowledgments:}

We acknowledge the personnel of the hemodialysis centers of Tanta University Hospital for their cooperation in collecting the samples.
Declaration of interest: The authors have no conflict of interest.

\section{References}

1- LEVIN A. and STEVENS P.E.: Summary of KDIGO 2012 CKD Guideline: Behind the scenes, need for guidance, and a framework for moving forward. Kidney International, 85 (1): 49-61, 2014.

2- BARSOUM R.S.: End-stage renal disease in North Africa. Kidney International, 63: S111-S4, 2003.

3- HAROUN M.K., JAAR B.G., HOFFMAN S.C., COMSTOCK G.W., KLAG M.J. and CORESH J.: Risk factors for chronic kidney disease: A prospective study of 23,534 men and women in Washington County, Maryland. Journal of the American Society of Nephrology, 14 (11): 2934 41, 2003.

4- BELLO A.K., ALRUKHAIMI M., ASHUNTANTANG G.E., BASNET S., ROTTER R.C., DOUTHAT W.G., et al.: Complications of chronic kidney disease: Current state, knowledge gaps, and strategy for action. Kidney International Supplements, 7 (2): 122-9, 2017.

5- VALDERRÁBANO F., HÖRL W.H., MACDOUGALL I.C., ROSSERT J., RUTKOWSKI B., WAUTERS J.P.: PRE-dialysis survey on anaemia management. Nephrology Dialysis Transplantation, 18 (1): 89-100, 2003.

6- TANAKA M., KOMABA H. and FUKAGAWA M.: Emerging Association Between Parathyroid Hormone and Anemia in Hemodialysis Patients. Therapeutic Apheresis and Dialysis, 2018.

7- DRÜEKE T.B. and PARFREY P.S.: Summary of the KDIGO guideline on anemia and comment: Reading between the (guide) line (s). Kidney International, 82 (9): 952-60, 2012.

8- SHAHBAZIAN H., GHORBANI A., ZAFAR-MOHTASHAMI A., BALALI A., ALEALI A. and LASHKARARA G.R.: Administration of pentoxifylline to improve anemia of hemodialysis patients. Journal of Renal Injury Prevention, 6 (1): 61, 2017.

9- FERRARI P., MALLON D., TRINDER D. and OLYNYK J.K.: Pentoxifylline improves haemoglobin and interleukin6 levels in chronic kidney disease. Nephrology, 15 (3): 344-9, 2010.

10- PHROMMINTIKUL A., HAAS S.J., ELSIK M., KRUM H.: Mortality and target haemoglobin concentrations in anaemic patients with chronic kidney disease treated with erythropoietin: A meta-analysis. The Lancet, 369 (9559): 381-8, 2007.

11-DEL VECCHIO L. and LOCATELLI F.: Anemia in chronic kidney disease patients: Treatment recommendations and emerging therapies. Expert Review of Hematology, 7 (4): 495-506, 2014.

12- YEUN J.Y., LEVINE R.A., MANTADILOK V. and KAYSEN G.A.: C-reactive protein predicts all-cause and cardiovascular mortality in hemodialysis patients. American Journal of Kidney Diseases, 35 (3): 469-76, 2000.

13- KALANTAR-ZADEH K.: Editor Recent Advances in Understanding the Malnutrition-Inflammation-Cachexia Syndrome in Chronic Kidney Disease Patients: What is Next? Seminars in dialysis. Wiley Online Library, 2005. 
14- STREETZ K., WÜSTEFELD T., KLEIN C., MANNS M. and TRAUTWEIN C.: Mediators of inflammation and acute phase response in the liver. Cellular and molecular biology (Noisy-le-Grand, France), 47 (4): 661-73, 2001.

15- SUFFREDINI A.F., FANTUZZI G., BADOLATO R., OPPENHEIM J.J. and O'GRADY N.P.: New insights into the biology of the acute phase response. Journal of Clinical Immunology, 19 (4): 203-14.

16-EBERSOLE J.L. and CAPPELLI D.: Acute-phase reactants in infections and inflammatory diseases. Periodontology, 23 (1): 19-49, 2000.

17- KURAGANO T., KITAMURA K., MATSUMURA O., MATSUDA A., HARA T., KIYOMOTO H., et al.: ESA hyporesponsiveness is associated with adverse events in Maintenance Hemodialysis (MHD) patients, but not with iron storage. PloS One, 11 (3): e0147328, 2016.

18- SCHILLER B., DOSS S., DE COCK E., DEL AGUILA M.A. and NISSENSON A.R.: Costs of managing anemia with erythropoiesis-stimulating agents during hemodialysis: A time and motion study. Hemodialysis International, 12 (4): 441-9, 2008.

19-TONELLI M., HEMMELGARN B., REIMAN T., MANNS B., REAUME M.N., LLOYD A., et al.: Benefits and harms of erythropoiesis-stimulating agents for anemia related to cancer: A meta-analysis. Canadian Medical Association Journal, 180 (11): E62-E71, 2009.

20- COOPER A., MIKHAIL A., LETHBRIDGE M.W., KEMENY D.M. and MACDOUGALL I.C.: Pentoxifylline improves hemoglobin levels in patients with erythropoietin-resistant anemia in renal failure. Journal of the American Society of Nephrology, 15 (7): 1877-82, 2004.
21- GONZÁLEZ-ESPINOZA L., ROJAS-CAMPOS E., MEDINA-PÉREZ M., PENA-QUINTERO P., GÓMEZNAVARRO B. and CUETO-MANZANO A.M.: Pentoxifylline decreases serum levels of tumor necrosis factor alpha, interleukin 6 and C-reactive protein in hemodialysis patients: Results of a randomized double-blind, controlled clinical trial. Nephrology Dialysis Transplantation, 27 (5): 2023-8, 2011.

22- MORTAZAVI M., SEYRAFIAN S., TAHERI S., NASIRI R., DOLATKHAH S., NAINI A.E., et al.: Role of pentoxifylline in treatment of anemic patients suffering chronic hemodialysis: A randomized clinical trial. Medical Archives, 66 (2): 84, 2012.

23- BOLIGNANO D. and D'ARRIGO G.: PISANO A., COPPOLINO G.: Pentoxifylline for anemia in chronic kidney disease: A systematic review and meta-analysis. PloS One, 10 (8): e0134104, 2015.

24- NAVARRO J.F., MORA C., GARCÍA J., RIVERO A., MACÍA M., GALLEGO E., et al.: Effects of pentoxifylline on the haematologic status in anaemic patients with advanced renal failure. Scandinavian Journal of Urology and Nephrology, 33 (2): 121-5, 1999.

25- MORA-GUTIÉRREZ J.M., FERRER-NADAL A. and GARCÍA-FERNÁNDEZ N.: Effect of pentoxifylline on anaemia control in haemodialysis patients: Retrospective observational case-control study. Nefrologia, 33 (4): 524 31, 2013.

26- ANTUNES S.A., VILELA R.Q., VAZ J.D. and CANZIANI M.E.F.: Pentoxifylline does not alter the concentration of hepcidin in chronic kidney disease patients undergoing hemodialysis. The International Journal of Artificial Organs, 37 (7): 521-8, 2014.

\section{تأثير العلاج بعقار البنتوكسفيللين على مستوى الهيموجلوبين بمرضى الأستصفاء الدموى ملئوى}

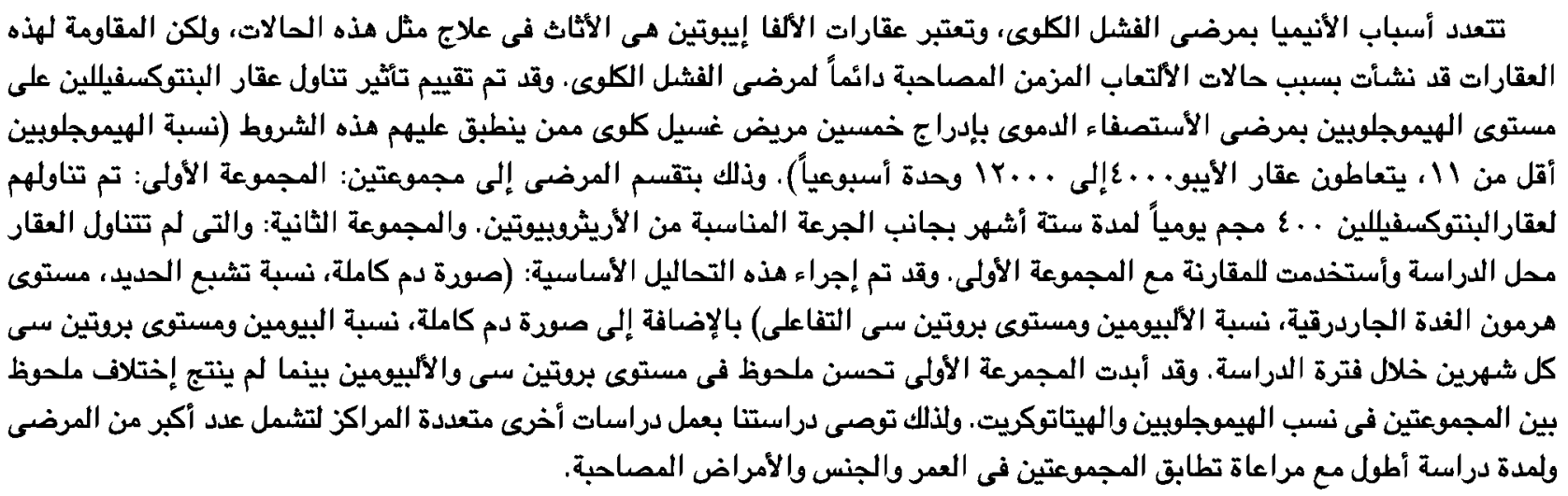

